\title{
Botanical expedition in mountains of Caucasus in 2013
}

Gennady A. Firsov ${ }^{1 \dagger}$

\begin{abstract}
SUMMARY
[EDITOR'S NOTE]

The botanical expedition has an important role in documenting unknown flora and its natural history. Such expedition has been instrumental to ascertain what conservation actions the region need of. Gennady A. Firsov writes a short note providing a fascinating account of a botanical expedition in the Caucasus Mountains. His vivid account of geography, climate and flora provide a resemblance between floral diversity with that of physical geography and climate. The six member expedition team visited the highest peak of Caucasus, the Bermamyt plateau, Teberda and Tuman- Lykyel Lake. Teberda, in particular, is a unique floral sanctuary where three seasons can be witnessed at the same time: warm summer down the valley, early spring in alpine meadow and winter further up with snowy storms, glaciers and everlasting snows. The Teberda Biospherical State Nature Reserve harbors 43 species of mammals. The tallest tree $(60 \mathrm{~m})$ measured in the expedition was Nordmann's Fir, which is considered tallest species in Russia. The explorers visited the gorge of Gonachkhir River and the Kyzgych gorge. The Kyzgych gorge is strictly protected regime where flock of aurochs lives in the wild. Here, the team found Lonicera steveniana Fisch. ex Pojark for the first time. They were lucky enough to discover Acer tataricum L. and Euonymus nanus Bieb. in Razvalka mountain.
\end{abstract}

KEYwords Botanical expediton, Russia, Teberda, mountains

Author Contribution GF wrote manuscript

Competing InTERest Author declares no competing interest.

Funding Komarov Botanical Institute

\section{Conservation Note}

ARTicle History

Received 05 July 2017

Revised 17 August 2017

Accepted 26 September 2017

Academic Editor

Prakash K Paudel

\section{Correspondence}

Peter the Great Botanic Garden of the Komarov Botanical Institute. Prof. Popov Street 2, 197376, Saint-Petersburg, Russia

Tel: ++7950030 6542

E-mail: gennady_firsov@mail.ru

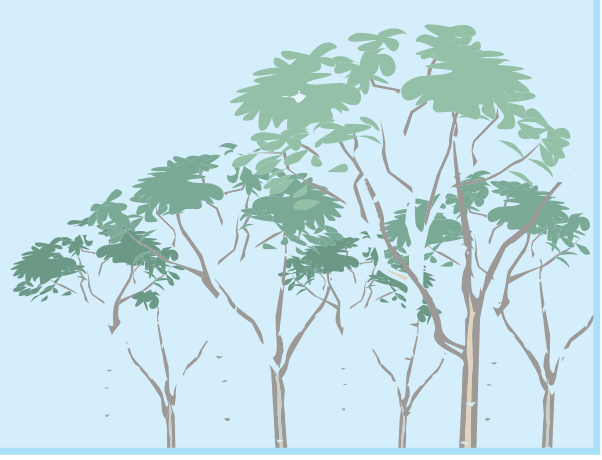

${ }^{1}$ Peter the Great Botanic Garden of the Komarov Botanical Institute. Prof. Popov Street 2, 197376, Saint-Petersburg, Russia

\section{Background}

Russia is blessed with unique endemic floral diversity of global conservation significance (Krasnaya kniga 2008). One of the significant places from botanical point of view is the Caucasus Mountains. It consists of more than 5000 species of vascular plants. The investigation of Caucasian flora began from early 1700s. The first samples were collected by Tournefort in 17001702 that were kept in Paris. These samples served to Carl von Linne as a material on describing many Caucasian species. The investigation of North Caucasus began in the beginning of the 18th century on initiative of Russian Tsar Peter the Great who himself visited Caucasus in 1722 (Takhtajan 2003).

\section{Location}

The Caucasus is situated in between Boreal and Mediterranean floristic sub kingdoms. It is astonishingly rich in floral diversity (Figure 1). Komarov Botanical Institute of
Russian Academy of Sciences (Saint-Petersburg, Russia) and its predecessors had a vital role in documenting Caucasian flora. The first and the second Directors of Imperial SaintPetersburg Botanic Garden (the older name of the Komarov's) - F. Fischer and C. A. Meyer - have made a huge contribution in generating knowledge of this region (Geltman, 2010). Rudolf Trautvetter (Figure 2), a prominent scientist and one of the first Directors of Imperial Saint-Petersburg Botanic Garden, was fascinated with Caucasian plants. The popular mountainous Caucasian maple Acer trautvetteri Medw., a well known in plant in horticulture, was named after him (Figure 2).

\section{The Context}

The "Flora of the USSR", a monumental record of all higher plants of Soviet Union, promoted the emerging interest 


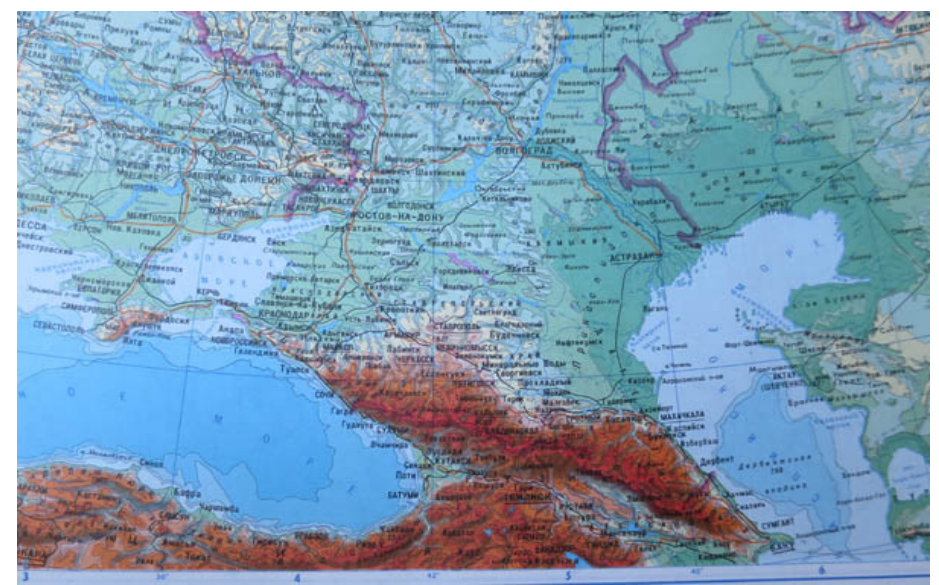

Figure 1 A location map of Caucasus Mountain (top) and Pjatigorsk and N. Caucasus (right)

in flora of Caucasus. All authors of this fundamental edition visited Caucasus personally and contributed for documenting flora diversity of this region (Geltman 2010). The prominent researcher of Caucasus, A. A. Grossheim, published a well-known book "Flora of Caucasus" who had worked at Komarov Botanical Institute. Academician Armen Takhtajan (1910-2009) also contributed massively to expand knowledge of Caucasus flora (Averyanov 2010). First, he was invited at Komarov as a staff in 1954 and subsequently became the Head of Department of Higher Plants in 1962. He trained future prominent experts-Yuri Menitsky and Tamara Popova- who worked under his supervision for a long time. Armen Takhtajan initiated a new project "Conspectus of Flora of Caucasus" in 1985 and published a detailed account of flora of Caucasus (Geltman 2010). The Komarov Botanical Institute was established in the Caucasus with its own departments and research station. The Ecological-Botanical Station was established in Pjatigorsk in 1986 that played a vital role in documenting Caucasus flora and their conservation (Melikova 2010).
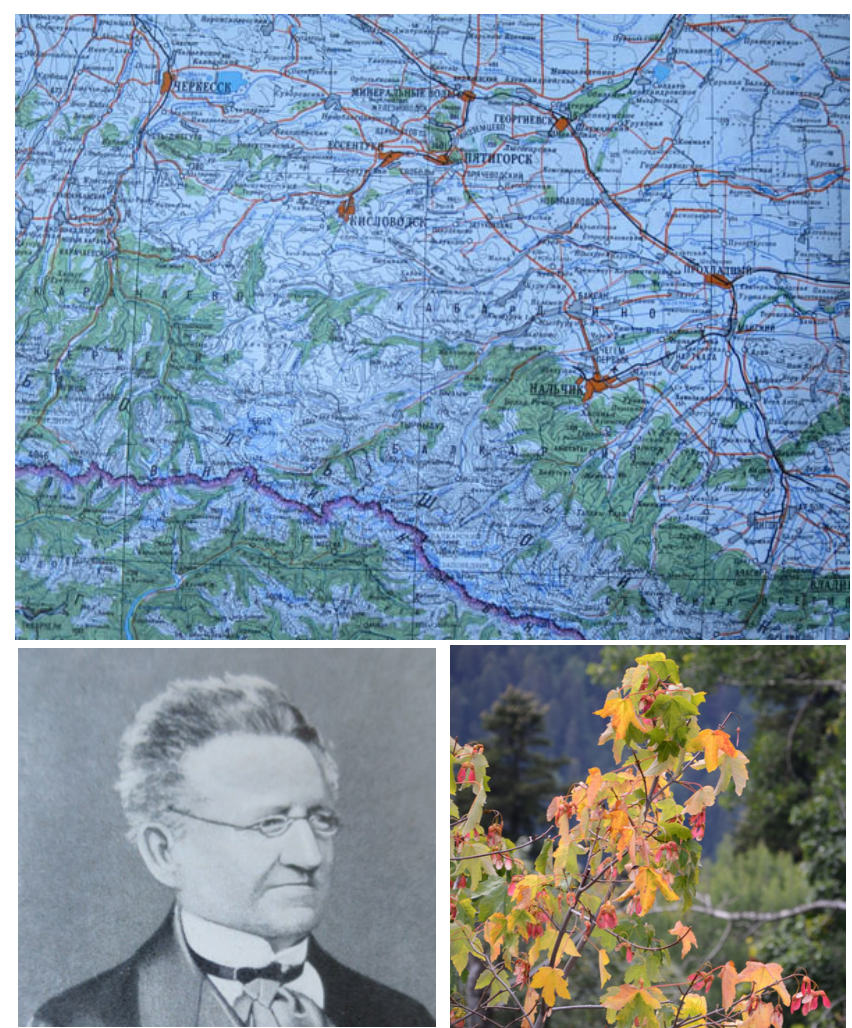

Figure 2 Rudolf Trautvetter one of the first Directors of Imperial Saint-Petersburg Botanic Garden. The Caucasian maple Acer trautvetteri Medw. is named after him (pictured).

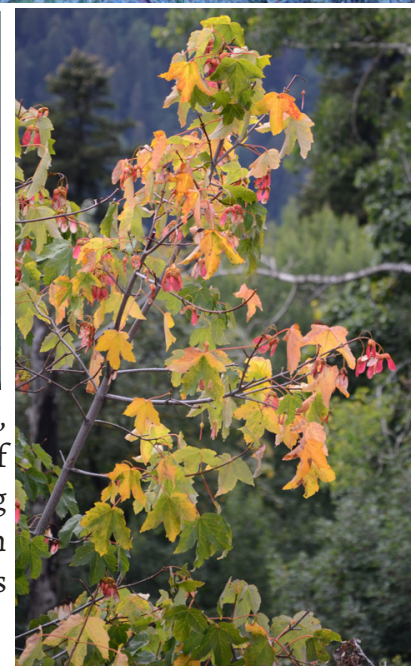

Stavropolsky kraj, a central part of Northern Caucaus, is very rich in floral diversity and endemism. This area harbors a total of 116 species of vascular plants, nearly half of them are described in environs of Pjatigorsk. The Beshtau Mountain is the locus classicus for most of them. An Ecological-Botanical Station is situated close to the Beshtau Mountain.

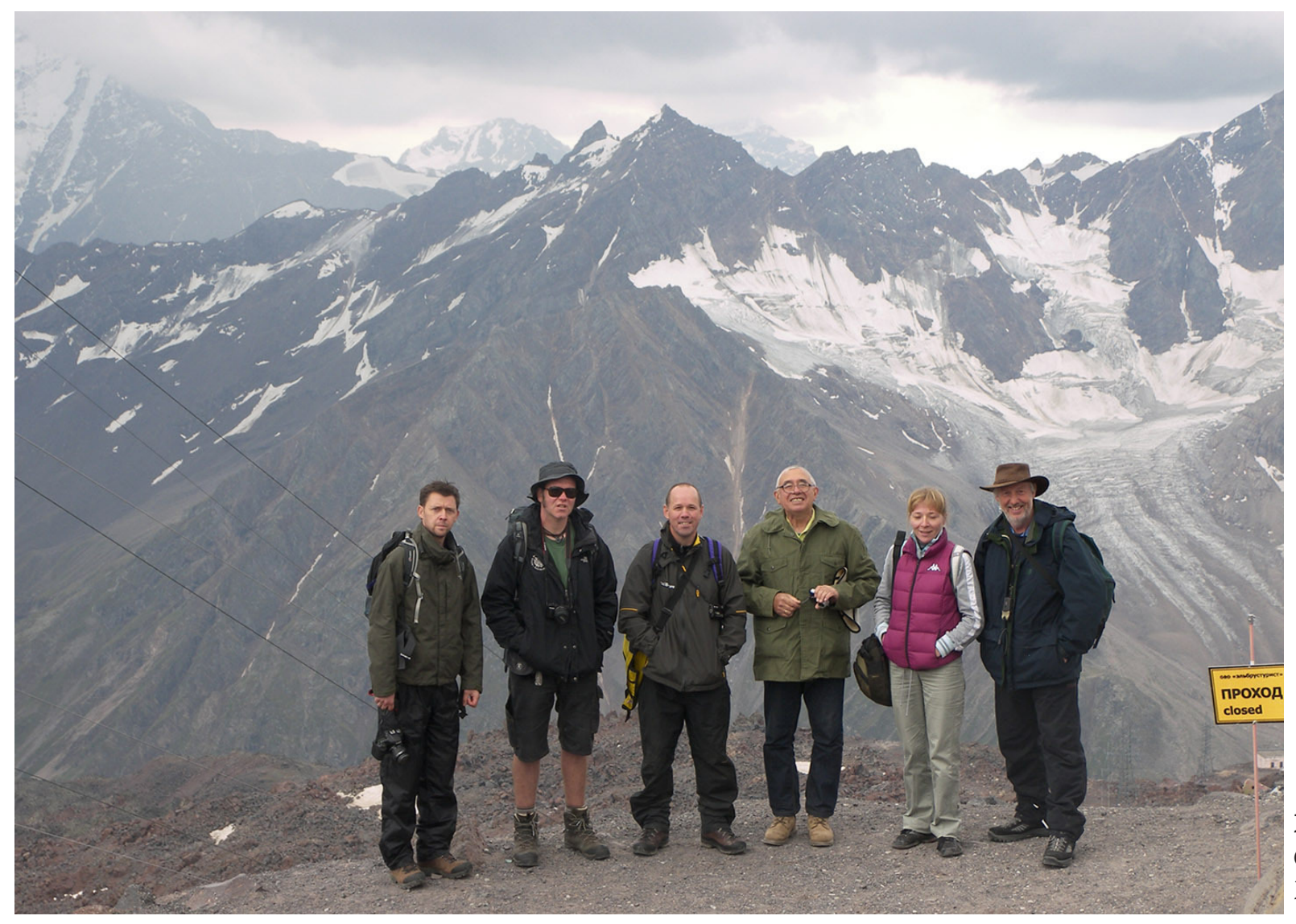




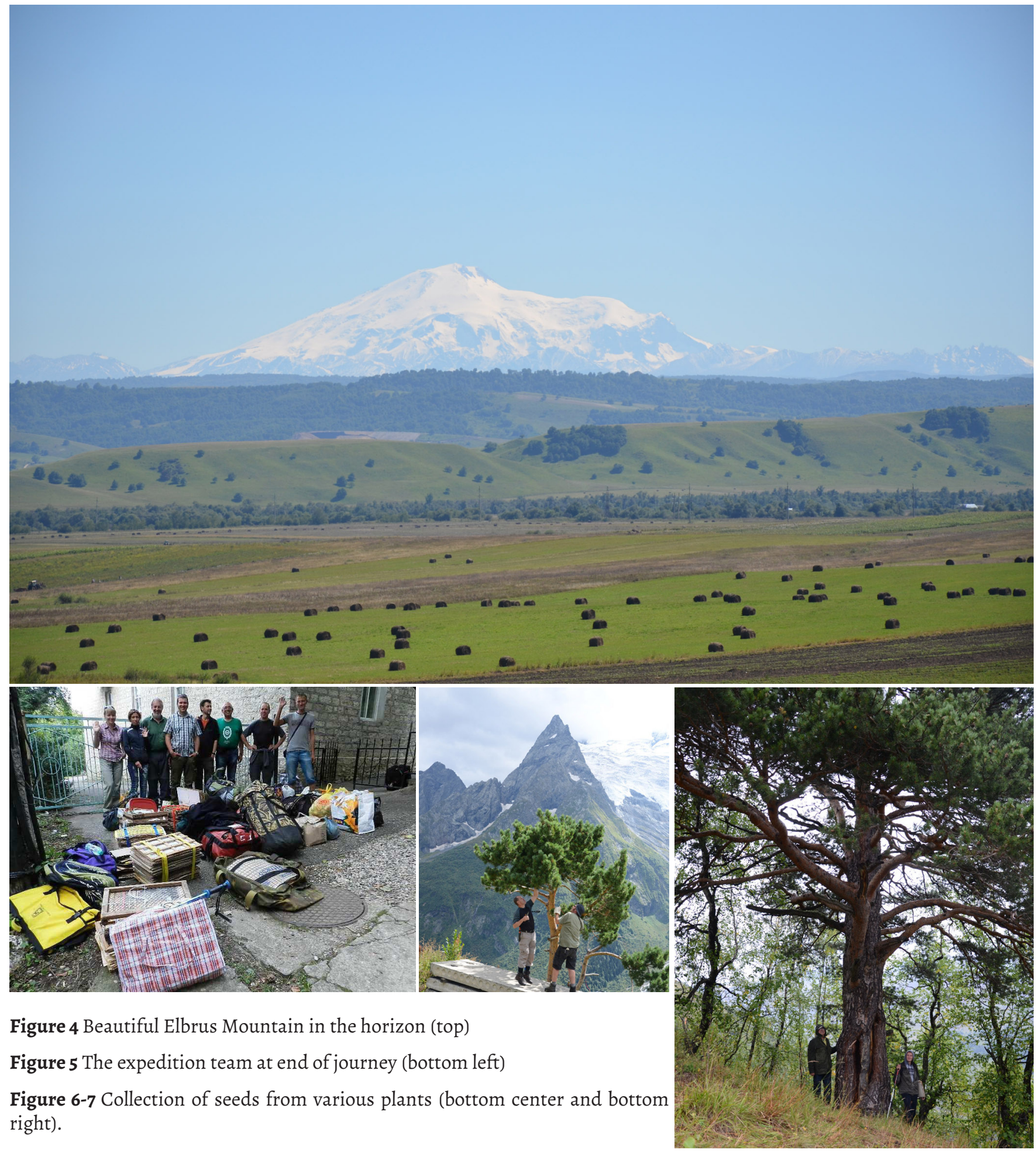

We embarked a journey to the Caucasus on 29 August 2013 with aim of collecting samples of seeds in wild to promote their ex-situ conservation (Figure 3). Our team included six experts from Royal Botanic Garden, Edinburgh, Royal Botanic Gardens, Kew and Howick Arboretum (United Kingdom) including dendrologists from Peter the Great Botanic Garden of Komarov Botanical Institute (Figure 5). Dmitry Shilnikov, well known expert of native Caucasuian flora, was our local guide, who has recently published two books on flora of Caucasus "Conspect of Flora of KarachajCircassian Republic" (2010) and "Rare and Threatened Plants of Karachaj-Circassian Republic" (2011). We began our expedition by visiting Elbrus - the highest peak of Caucasus (Figure 4). Kabardian-Balkar Republic is rich in woody flora with 214 species from 38 families of 79 genera (Thasaplizheva and Shkhagapsoev 2010). We reached a small village in the evening which lies at the left bank of the Baksan River. The river joins Shkhelda River at $1760 \mathrm{~m}$ altitude, in the foothill of the Elbrus Mountain consisting fine pine forest of Pinus kochiana Klotzsch. We collected seeds of Berberis vulgaris L. and Miricaria bracteata Royle, which were the first samples of our expedition (Figure 6-7). During sunset, we enjoyed a spectacular view of rapid, murmuring and turbulent river, which got chocolate-colored in the gorge of the mountains.

Next day, we reached at $3800 \mathrm{~m}$ above sea level by an elevator in the early morning. It was above the timberline and alpine meadows and covered by icy desert with glaciers and everlasting snows (Figure 8). Dwarf sized plants such as Draba bryoides DC. are common here. We enjoyed local meals: Shorpa soup from mutton and khychins (kind of pies 


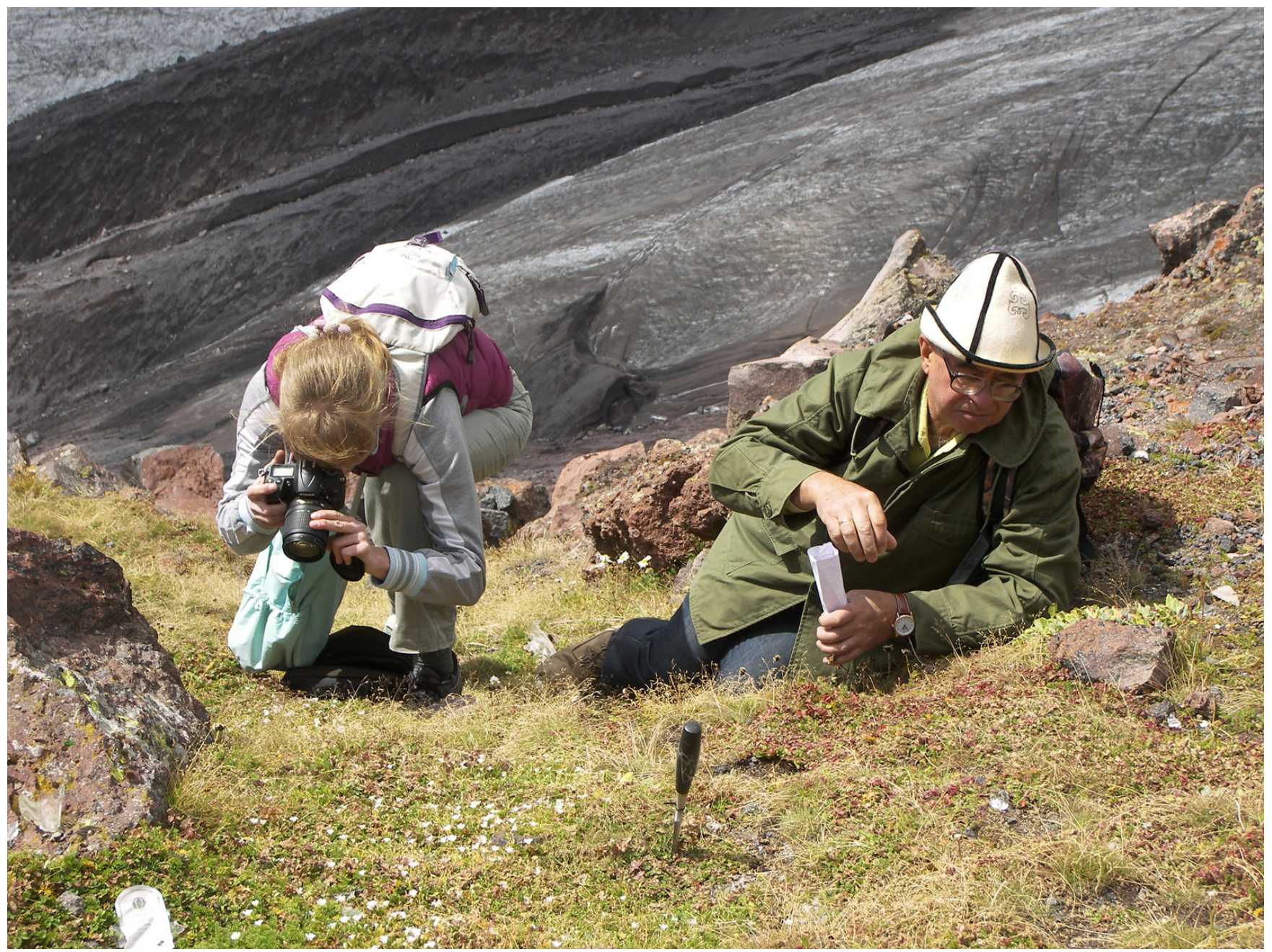

Figure 8 Expert Collecting seeds in Elbrus

with cheese or meat) - in such high altitude (ca $3500 \mathrm{~m}$ ). Tea made from native mountain herbs -leaves of evergreen Rhododendron caucasicum Pall. including Thymus sp., Origanum vulgare L., Rubus idaeus L., Rosa sp. and other herbs (leaves and flowers, sometimes fruits) - was unique, which gave a refreshing experience. By the evening, we reached Narzan Valley, where we collected seeds of trees and shrubs (Figure 9). The next day, we slowly climbed Cheget Mountain through a dense forest of pine (mainly Pinus kochiana Klotzsch ex C. Koch), some of which might be hundred years old. Here, we

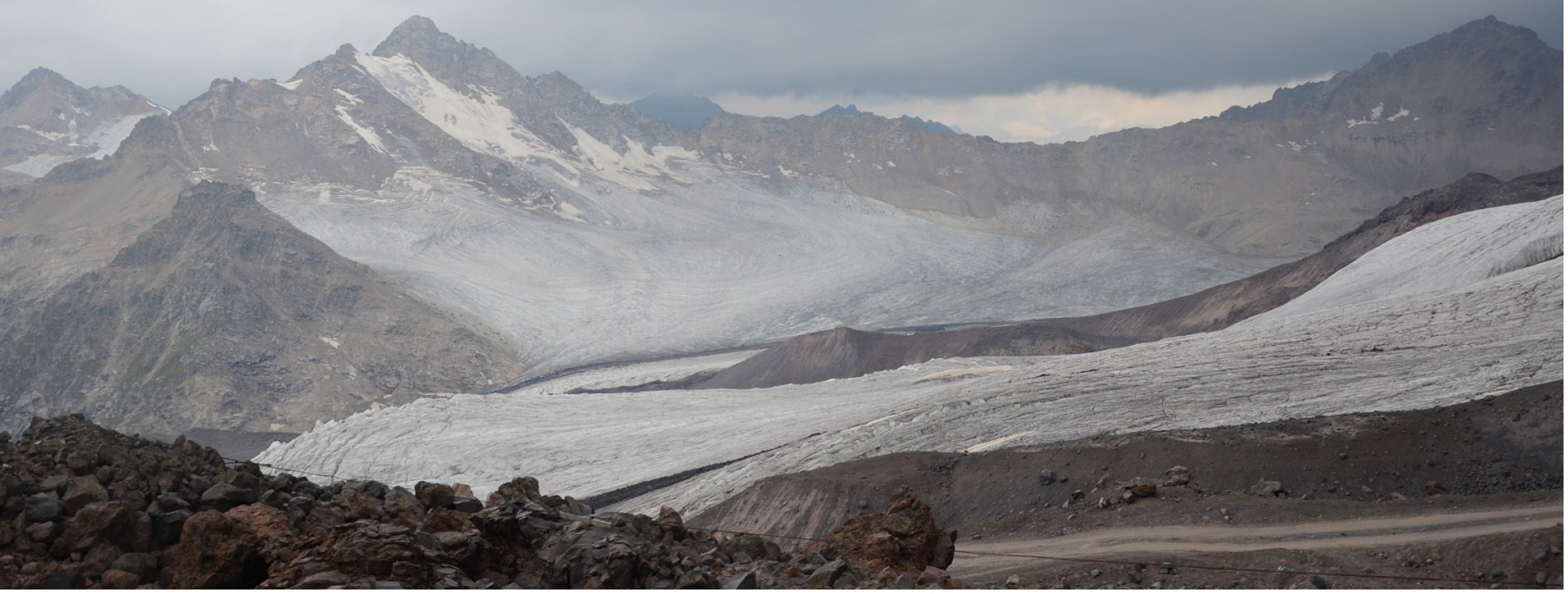

Figure 9 Moutain desert above timberline 

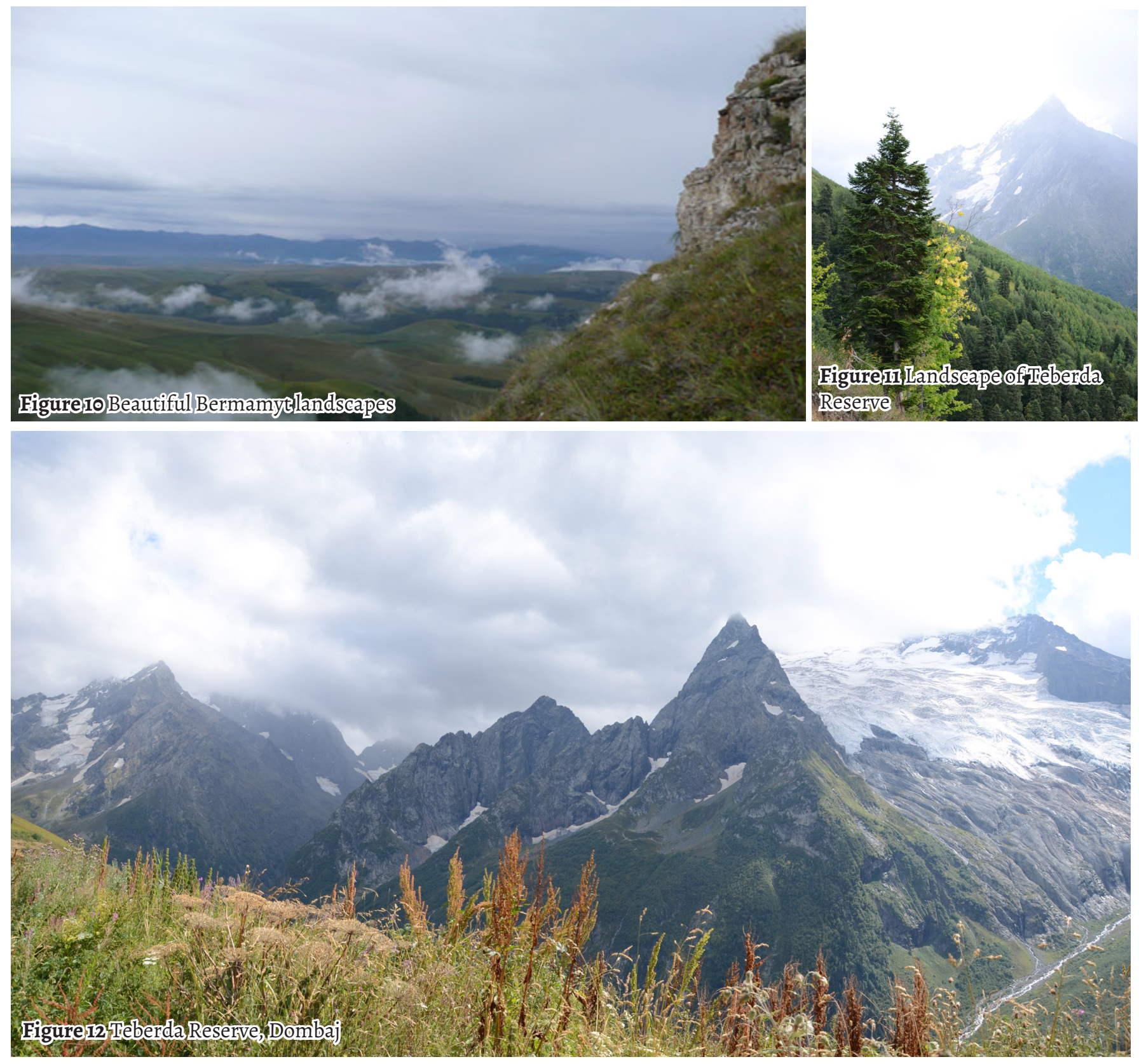

collected large seed pods of Lilium kesselringianum Miscz. including Allium victorialis L.. We were quite anxious as it was getting dark and raining heavily. We therefore did not stop on the way in marvelous Baksan gorge to look for endemic Daphne baksanica Pobed. Our aim was to reach Medoviye Vodopady (The Honey Waterfalls), an unsettled area with unspoiled nature that supports many endemic plants. It is situated in picturesque gorge in the left bank of Alikonovka River (1070 $\mathrm{m}$ asl). Here we collected seeds of Rhamnus pallasii Fisch. et C.A. Mey., Amelanchier ovalis Medik. and Rosa terskolensis Galushko. Next day, $1^{\text {st }}$ September, the first day of autumn, was difficult to walk due to torrent rains with cold strong wind. We headed towards the Bermamyt Plateaue (Figure 10) by a vehicle. The area is characterized by short summer and cold windy winter and has always been a place of great interest for botanists dealing with alpine plants. We collected several endemic and typically alpine plants such as Campanula saxifraga Bieb., Salvia glutinosa L., Scabiosa caucasica Bieb. We then went to Teberda, where we had breakfast at 8 am: porridge, mountain tea from local herbs and pancakes with cherry jam and Caucasian honey. It was one of few days with good sunny weather. There was a stop on the way before the Gum-Bashi Pass (translated as Sandy Pass). We observed trees common for us like Alnus incana (L.) Moench and Salix caprea L. at mountain floodland forest along Podkumok River and their associates like Fagus orientalis Lipsky and Quercus robur L. There were bee-keepers along the road where travelers stop and buy fragrant honey. We reached the top of the Pass (about $2000 \mathrm{~m}$ ) by climbing up through a serpentine road. Here we enjoyed with beautiful landscapes of peaks of the Skalisty Range. We were aware of our mission and collected seeds of Veratrum lobelianum Bernh., a poisonous but very decorative and impressive perennial plant. We reached Karachayevsk on the noon at 2 pm, the main town of this Republic, but we continued our journey. By evening, we arrived Teberda where office of Teberda Biospherical State Nature Reserve (113,064 hectares) is situated.

The Teberda Biospherical State Nature Reserve was established in 1936 to protect its unique biodiversity. It is situated at the northern slopes of the Main Caucasian Ridge, which divides it from Abkhazia. The area is a typical mountain highland with elevations ranging from $1,260 \mathrm{~m}$ to $4047 \mathrm{~m}$ above sea level (the highest top of Dombai-Ulgen Mountain). Such a high altitudinal gradient is one of the determinants of exceptionally rich in floral diversity, which included 1270 species of vascular plants, including 272 endemic plants (Vorobjeva and Kononov, 1991). Nearly $85 \%$ of territory lies at elevations above $2000 \mathrm{~m}$. It is a peculiar 
place where one can see three seasons of the year in the same time: a warm summer downwards at the valleys, early spring - at the alpine meadow, and further up - a winter with snowy storms, glaciers and everlasting snows (Figure 1112). Teberda is about $50 \mathrm{~km}$ long located along the Caucasus Mountains between the Black Sea and the Caspian Sea. The highest mountain of Europe - Elbrus (5642 m) -is situated in the East. The Teberda harbors many glaciers $(n=85)$ and some of them are large. The glaciers make up $10 \%$ of the whole territory $\left(61 \mathrm{~km}^{2}\right)$ (Salpagarov, 2006). These glaciers are the perpetual sources of water and feed a total of 30 rivers. The region has also 130 lakes at altitude between $2700 \mathrm{~m}$ and 3000 $\mathrm{m}$. The area has 43 species of mammals and some of them survive here only (Salpagarov, 2006). The forests of Teberda play a significant role in soil and water protection. Twentyfour species of vascular plants of Teberda Reserve are listed in the Red Data Book of Russian Federation (Vorobjeva and Kononov, 1991) (Table 1).

We reached "The House of Forester", a comfortable inn, before sun set and enjoyed a good time with colleages. Next day, we were warmly welcomed by Dzhamal Tekiev, the Deputy Director of Teberda Nature Reserve. Dombaj is well known resort town. It is a popular destination for rest and skiing in winter and for hiking in summer, especially for sportsmen. Dombaj is surrounded by high and steep slopes mostly covered with dark gloomy woods, mostly of Abies nordmanniana (Stev.) Spach and sometimes, bare rocks and cliffs without vegetation.

We ascended mountain by an elevator $(2520 \mathrm{~m})$ and collected alpine meadow ( Pulsatilla aurea (Somm. et Levier) Juz., Pedicularis atropurpurea Nordm. and Hedysarum caucasicum Bieb). This alpine meadow has many floras popular for horticulture and decorative gardening. After examining the meadow, we slowly descended along slope of Mussa-Achitara Mountain upto the timber line. We measured several trees close to our path. The tallest tree that we measured was Nordmann's Fir, which had $55 \mathrm{~m}$ height and
$374 \mathrm{~cm}$ circumference. Some report suggest that this conifer species is considered as the tallest tree in Russia, which can be as much as $60 \mathrm{~m}$ high and attain $2 \mathrm{~m}$ trunk diameter (Figure 13). Some trees are considered 600 years old. This is one of the most valuable and endemic plants to the Caucasus and adjacent areas of Turkey. The forest of Caucasian Fir is common at elevations between $1300 \mathrm{~m}$ and $2200 \mathrm{~m}$ in the southern part of Teberda Reserve. Acer trautvetteri with colored orange leaves gives astonishing beautiful picturesque in the background of dark green spruces and fir trees. We enjoyed scenery of waterfalls and remote peaks in blue mist. At some places, we saw broken trees of pines and firs as a result of avalanches. It was already late when we reached Dombaj. We rushed to our inn to prepare herbarium, and clear, dry and organize seeds instead of strolling outside to look at local souvenirs offered for tourists.

The next morning, on receiving the special pass, we visited the gorge of Gonachkhir River and Tuman-Lykyel Lake. This small lake with pure crystal water is situated at an elevation of $1900 \mathrm{~m}$ above sea level. After spending some time to collect seeds, we drove down the gorge at confluence of Gonachkhir river and $\mathrm{Bu}$-Ulgen river, and took a break for lunch under huge trees of Picea orientalis (L.) Link. Here, we collected Chamaenerion dodonaei (Vill.) Kost.. We took a photo for memory near the very big Abies nordmanniana tree which is placed on the cover of the British Conifer Society Journal (Firsov, Alexeeva, Shilnikov, 2012). In the evening, there was a supper with Alexej von Bock, a well-known alpinist and expert on glaciers and Deputy Director of Teberda Nature Reserve.

Many local people consider Arkhyz as the best place of Caucasus (Figure 14). It is famous for quality mineral water. The next day, we travelled to this beautiful gorge. There was chilly cold because of strong wind from mountains covered with snow. We found nothing to collect here as grass was eaten by sheep. At the lower part of this mountain, we found Pyrus caucasica Fed. Its small tough fruits with stony

Table 18 Species listed in the Red Data Book of Russian Federation

\begin{tabular}{ll}
\hline SN & Species name (family) \\
\hline 1. & Atropa caucasica Kreyer (Solanaceae) \\
2. & Cephalanthera longifolia (L.) Fritsch (Orchidaceae) \\
3. & Cephalanthera rubra (L.) Rich. (Orchidaceae) \\
4. & Colchicum speciosum Stev. (Melanthiaceae) \\
5. & Crocus vallicola Herb. (Iridaceae) \\
6. & Dactylorhiza sanasunitensis (Fleischm.) Soo (Orchidaceae) \\
7. & Dactylorhiza triphylla (C. Koch) Czer. (Orchidaceae) \\
8. & Elytrigia stipifolia (Czern. ex Nevski) Nevski (Poaceae) \\
9. & Epipogium aphyllum Sw. (Orchidaceae) \\
10. & Euonymus nanus Bieb. (Celastraceae) \\
11. & Festuca sommieri Litardiere (Poaceae) \\
12. & Hordelymus europaeus (L.) Harz (Poaceae) \\
13. & Lilium kesselringianum Miscz. (Liliaceae) \\
14. & Orchis coriophora L. (Orchidaceae) \\
15. & Orchis mascula (L.) L. (Orchidaceae) \\
16. & Orchis militaris L. (Orchidaceae) \\
17. & Orchis picta Loisel. (Orchidaceae) \\
18. & Orchis ustulata L. (Orchidaceae) \\
19. & Paeonia caucasica (Schipch.) Schipch. (Paeoniaceae) \\
20. & Paeonia wittmanniana Hartwiss ex Lindl. (Paeoniaceae) \\
21. & Primula renifolia Volgun. (Primulaceae) \\
22. & Stipa pennata L. (Poaceae) \\
23. & Stipa pulcherrima C. Koch (Poaceae) \\
24. & Taxus baccata L. (Taxaceae). \\
\hline &
\end{tabular}

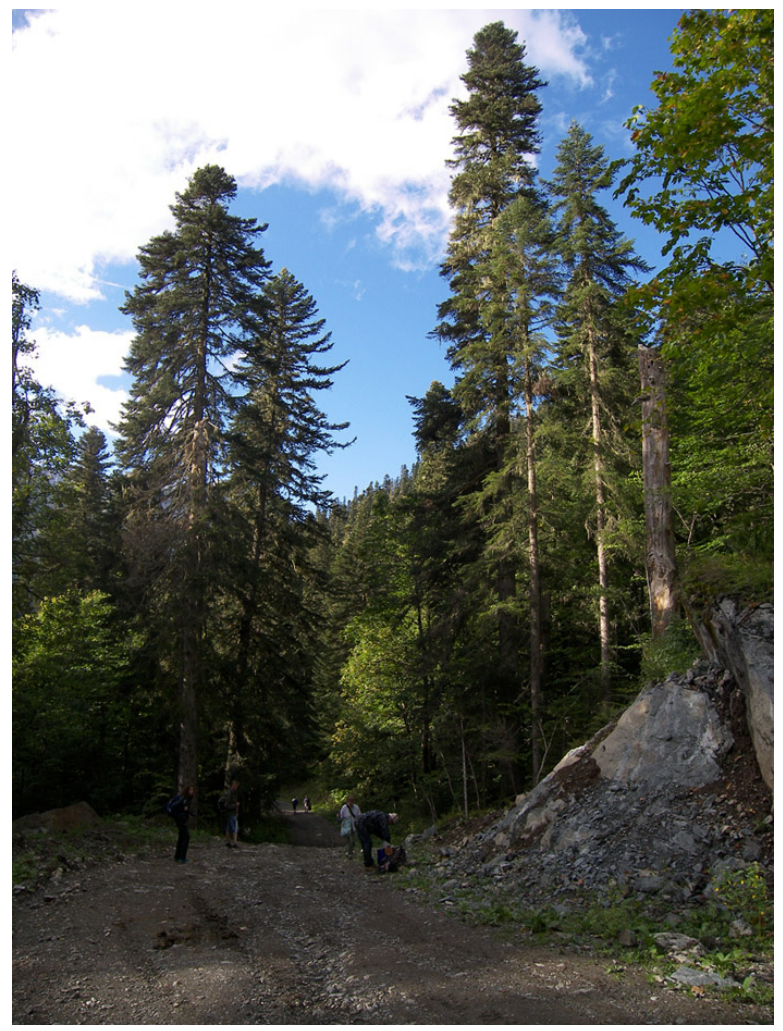

Figure 13 Huge silver fir tree (up to $55 \mathrm{~m}$ high) 


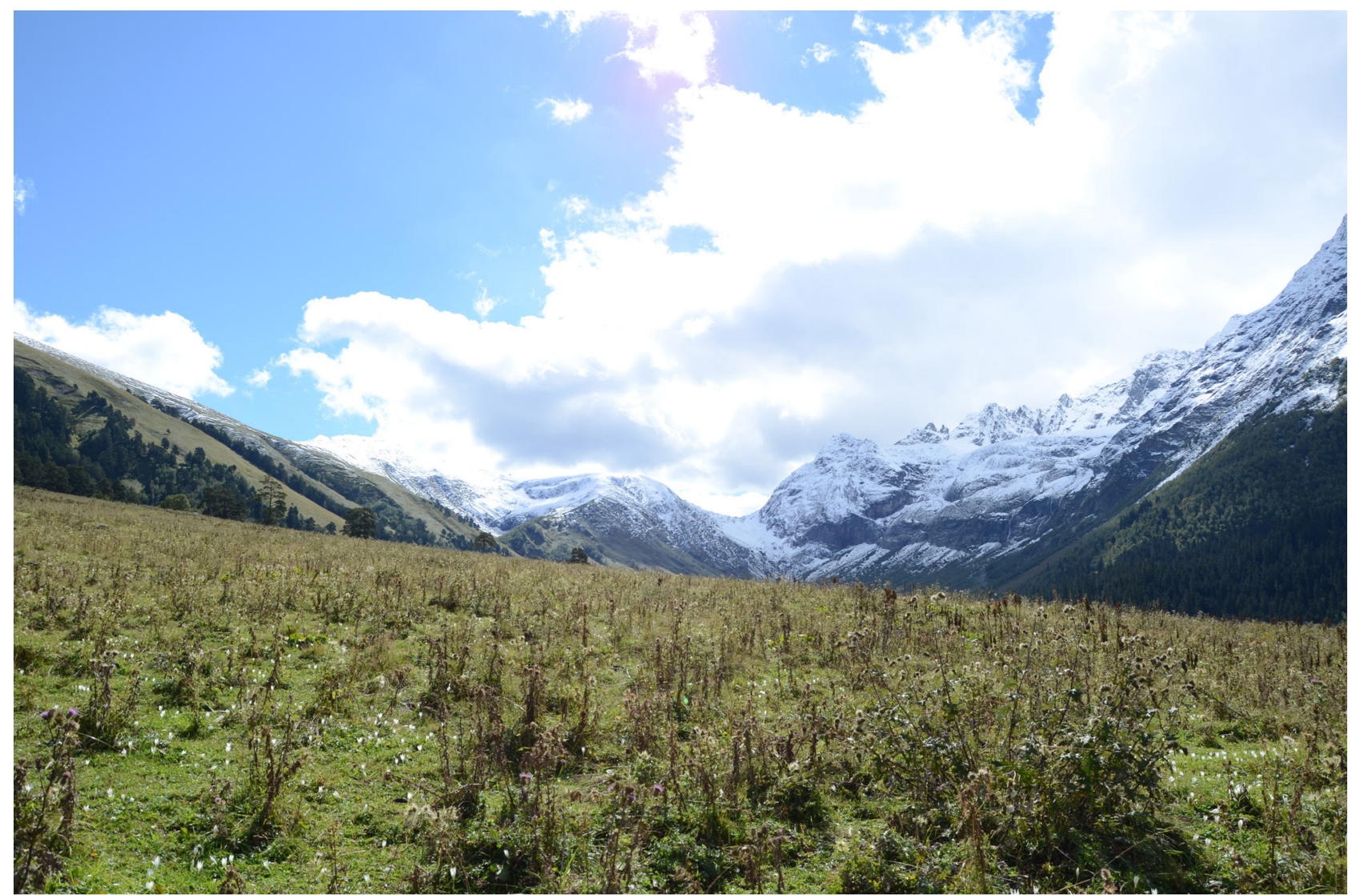

Figure 14 Arkhyz, Sofija Gorge

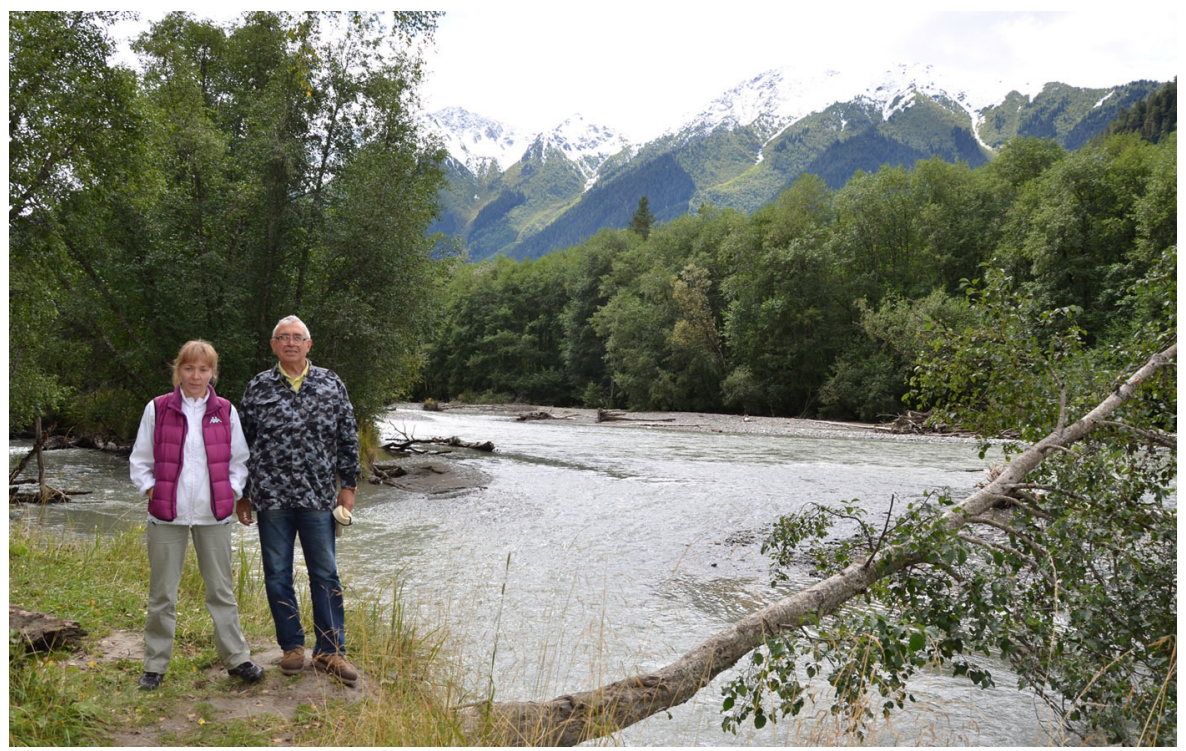

Figure 15 Kyzgych Gorge

flesh are not eatable but may be used for grafting. At other stop, we found Juniperus oblonga Bieb. without seeds which substitute European Juniperus communis L. in Caucasus. Our hotel "Energetic" was situated at picturesque left bank of the Bolshoj Zelenchuk River. We already had a huge stockpile of seeds collected from field and therefore we spent more time to manage these samples.

The Kyzgych Gorge (Figure 15) lies in the Teberda Nature Reserve which is strictly protected regime. This is only place where the flock of aurochs lives in the wild - these relic animal are absent outside of the borders of the Reserve (Salpagarov, 2006). We discussed the idea to rent horses for our botanical excursion, but finally went on foot. We slowly moved through mixed forest looking for new species. It was magnificent primary forest with domination of Pinus Ehrh.).
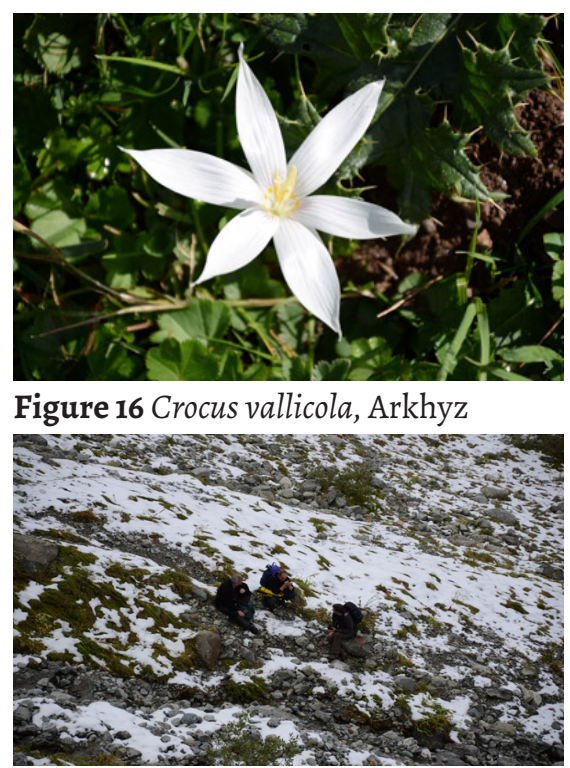

Figure 17 Seed collection in Kyzgych

kochiana of huge sizes in the first layer. The tallest pine was $39 \mathrm{~m}$ high and the widest one had $208 \mathrm{~cm}$ circumference. It was higher and thicker than according to official literature. The common Padus avium Mill here, at elevation of $1493 \mathrm{~m}$, was represented by multi-stemmed bush. It was here we found Lonicera steveniana Fisch. ex Pojark. first time in our expedition. There were also small trees of Sorbus aucuparia L. and shrubby thicket of Rosa (rich genus with many local species) and Berberis vulgaris. Seeds of decorative perennial Polygonatum verticillatum (L.) were a good addition to our collections. We collected Prunus divaricata Ledeb. (P. cerasifera

The $7^{\text {th }}$ September, Saturday, was the $10^{\text {th }}$ day and the peak of expedition. We departed to Sofija's Waterfalls, the beautiful gorge, about $25 \mathrm{~km}$ by a dirt road from Arkhyz 
village. The gorge was covered with white flowers of beautiful bulb - Crocus vallicola Herb. It was a stunning scene - the white Crocus flowers in the background of mountains covered with snow (Figure 16). In the evening, we discussed about staying in the tent, but we eventually dropped this idea to allow more time for arranging sample. Our collections included both woody and perennial species: Daphne glomerata Lam., Sibbaldia semiglabra C.A. Mey., Aconitum orientale Mill., Empetrum caucasicum Juz. and many others. It was difficult to penetrate through dense thicket of Rhododendron caucasicum, although pod were ripen, which is a good condition for collection. After enjoying with lovely view of Sofija's Waterfalls and having a rest near bon-fire, we returned to Arkhyz. The day passed away very quickly, like "five minutes".

The next day we were on the way to Pjatigorsk, with several stops for seed collections. It was interesting to examine the steep slope of dark and shady beech forest at Nizhnij Arkhyz village. Beautiful trees of Carpinus betulus L. Tilia begoniifolia Stev (T. platyphyllos Scop., subsp. caucasica (Rupr.) Loria) and Malus orientalis Uglitzk are found in such type of forest. Near Zelenchukskaya Cossack village there was a good place to make a beautiful picture from far away of snowy peak of Elbrus. Local people were harvesting the potato. We picked seeds of Elaeagnus caspica (Sosn.) Grossh. (E. angustifolia L. var. caspica Sosn.) in the town of Cherkessk and Suvorovskaya Cossack village, not far of border between Karachaj-Circassian Republic and Stavropolsky kraj, at 648 $\mathrm{m}$ above sea level. This was a single tree with wide crown at open plain steppe, about $7 \mathrm{~m}$ high. In the evening, we accommodated in a new place at Ecological-Botanical Station.

In morning, we had excursion to Arboretum in the morning. Perkalsky Arboretum consisted of more than 550 species of cultivated trees and shrubs. It is one of scientific departments of the Komarov Botanical Institute. The Arboretum was established at the end of the XIX century, long before the Station itself. This was the first scientific center of arboriculture at the North Caucasus (Melikova, 2010). We spent whole day in cleaning seeds and drying the herbarium specimens. After dinner, one hour before darkness, we had a short hiking up the Mashuk slopes along open rocks $(651 \mathrm{~m})$, where the most interesting trees and shrubs grow: Crataegus rhipidophylla Gand., Crataegus pentagyna Waldst. et Kit., Swida australis (C.A. Mey.) Pojark. ex Grossh., Ligustrum vulgare L., Cornus mas L., Sorbus torminalis (L.) Crantz. It was clear for us that the arboreal flora of Pjatigorsk is quite different from that of mountainous part of Large Caucasus. Sorbus graeca (Spach) Lodd. ex Schauer was one of the best findings - three-stemmed small tree growing near rock, up to $5 \mathrm{~m}$ high, heavily covered with delicious orange-red fruits. The evening, followed by unbelievable black night, was very warm, the summer returned for us.

The next day, $9^{\text {th }}$ September, we searched Acer tataricum L. and Euonymus nanus Bieb. in Razvalka Mountain near town of Zheleznovodsk. This is the neighboring town to Pjatigorsk. We were lucky to discover both of them (630$680 \mathrm{~m}$ elevation). Euonymus nanus is very rare and threatened species, very seldom at Caucasus. Rosa dolichocarpa Galushko. is another rare species. As a matter of fact, it is endemic to Caucasus and Razvalka Mountain. Acorns of Quercus petraea L. ex Liebl. were hanging on the tree, with visible cotyledons ready to germinate. Juglans regia L. and Acer platanoides L. produced profusely self-sowing in this broad-leaved forest - these trees belong to local flora. Tamus communis L., the
Adam's root, with large red berries, was a good addition to our collection of perennials.

The $10^{\text {th }}$ September was the $13^{\text {th }}$ day of expedition. We prepared for departure. But we were eager to look for undiscovered Acer laetum C.A. Mey. After lunch Dmitry Shilnikov organized in excursion in Essentuki - small town not so far from Pjatigorsk. We were lucky to find it in the forest near Gorny village, at the left bank of Yutsa River at $950 \mathrm{~m}$. The trees of this maple, about $13 \mathrm{~m}$ hight, produced the first layer of the forest in common with Carpinus betulus. Along the edge of the forest there was a shrubby thicket of Prunus spinosa L., Crataegus rhipidophylla, Viburnum opulus L. which were rather common in this area.

The next day was the last day of our expedition. We spent warm black southern night in a good restaurant situated along the slope of Mashuk Mountan. Even this day we picked several new interesting species such as Celtis glabrata Stev. ex Planch. We concluded our expediton successfully and met our objectives. The Russian participants of expedition met each other soon in Togliatti during the Congress of the Russian Botanical Society.

\section{Conclusions}

The flora of North Caucasus is rather well preserved. This is mostly because such high altitude zone has inhospitable climate and inaccessible to reach. Consequently, agricultural activity is very limited. The establishment of the protected territories also considerably contributed for the conservation of flora. However, anthropogenic disturbances with development of tourism activity and agriculture in the beginning of the XXI century had already affected area to some extent. Collection of more than 250 samples of seeds, including many new to our arboreta will promote ex-situ conservation.

\section{References}

Averyanov LV (2010). Armen Takhtajan and his role in the study of flora, vegetation and phytogeography of the Caucasus // Study of the flora of the Caucasus. Abstracts of the international conference (Pyatigorsk, September, 27 - October, 1, 2010). Pyatigorsk, 2010. P. 4-5.

Firsov G, Alexeeva N, Shilnikov D (2012) The Wonderful Conifers of Teberda and Arkhyz, The British Conifer Society Journal, 19:30-36.

Geltman DV (2010) Role of the Komarov Botanical Institute and its predecessors in the study of the Caucasian flora, study of the flora of the Caucasus. Abstracts of the international conference (Pyatigorsk, September, 27 - October, 1, 2010). Pyatigorsk. P. 28-29.

Krasnaya kniga Rossijskoj Federazii (rastenija i gribi)/ Chief ed. Yu.P. Trutnev; compilers R.V. Kamelin et al. Moscow: Tov. nauch. izd. KMK. 2008. 855 p.

Melikova LN (2010) Role of Ecological and Botanical Station "Pjatigorsk" in the study of the flora of the Caucasus, Study of the flora of the Caucasus. Abstracts of the international conference (Pyatigorsk, September, 27October, 1, 2010). Pyatigorsk. P. 75-76.

Salpagarov DS (2006) Teberdinsky zapovednik. Prirodoohrannaya i nauchnaya dejatelnost (19362006). Transactions of the Teberda State Biospheric 
Nature Reserve. Issue 42. Kislovodsk: Northern Caucasus Publishing House MIL. 2006. 431 p.

Shilnikov DS (2010). Conspect of Flora of Karachaj-Circassian Republic. Stavropol. 2010. 384 p.

Shilnikov DS (2011) Rare and Threatened Plants of KarachajCircassian Republic. Nalchik: Izd. M. and V. Kotljarov's. 2011. 492 p.

Takhtajan AL (2003) Caucasian Flora Conspectus. SaintPetersburg University Press. 2003. Vol. 1.
Thasaplizheva L, Shkhagapsoev S (2010) History of studies of flora and plant cover in Kabardino-Balkaria // Study of the flora of the Caucasus. Abstracts of the international conference (Pyatigorsk, September, 27 October, 1, 2010). Pyatigorsk, 2010. P. 108-109.

Vorobjeva FM, Kononov VN (1991) Flora of the Teberda Reserve (Vascular plants). Transactions of the Teberda Reserve. Issue XIII. Stavropol Publishing House. 1991. $136 \mathrm{p}$.

\section{Biography}

Gennady A. Firsov is a Curator of Dendrology at Peter the Great Botanic Garden. His research interest includes dendrology and arboriculture. He has published a total of 447 popular articles, research papers and monographs since 1979.

\section{Citation}

Gennady A. Firsov, G. A. (2017) Botanical expedition in mountains of Caucasus in 2013. Conservation Science, 1: 1-9. 